\title{
Transformation of Assessment of the Pre-Service Life Sciences Teachers: Issues of Curriculum Development in Education and Training in South Africa
}

\author{
Mamsi Ethel Khuzwayo \\ Cape Peninsula University of Technology Cape Town, in Mowbray South Africa \\ https://orcid.org/0000-0002-4084-8773 \\ Kwanele Booi \\ Cape Peninsula University of Technology Cape Town, in Mowbray South Africa \\ https://orcid.org/0000-0003-0611-2305
}

\begin{abstract}
The Department of Higher Education intends to transform the traditional education theories and practices in the education and training of teachers for the twenty-first century. The attributes of a competent and qualified teacher underpin the envisaged changes in the curriculum to aptly prepare teachers. However, the realizations of the intentions of the department appear to be in vain. Accordingly, the current case studies conducted through qualitative procedures aimed to investigate how teacher educators adhere to the proposals of the Minimum Requirement of Teacher Education Qualifications (MRTEQ). The data gathered through the analysis, of course, guides intended to search for the link between the Life Science curriculum content knowledge and the plan to assess the competences promulgated by the South African Qualification Authority (SAQA). The findings pointed out that the course guide indicated learning outcomes, critical outcomes, and course and module outcomes; however, the assessment criteria were not aligned to the learning outcomes, module outcomes, and assessment techniques or tools. Therefore, the study recommends that academics in teacher education should explore and reflect on the models that could explicitly measure the performance of competencies (foundational, practical, and reflexive) authentically and reliably.
\end{abstract}

Keywords: assessment; models; teacher education; curriculum; teacher educators 


\section{Introduction}

Literature developed after the ushering of the democratic government presents various experiences of the demands resulting from the educational policies on higher education, which introduced radical changes to transform the curriculum for teacher education and training. The academic policies expected teacher educators to understand and master the paradigm of Outcomes-Based Education (OBE) and Outcomes-Based and Competency-Based Assessment approaches that underpinned the Norm and Standard for Educators (NSE) gazetted by the Department of Basic Education in 1998. Reactions and reflections in researchers' work such as Jansen (1998); Chisholm (2005); Higgs (2007); Christie (2006); Gravett and Geyser (2004); Sayed and Kanjee (2013) pointed to the repercussions of the radical shift from the apartheid educational paradigm, highlighting the plight of teacher educators in terms of readiness for the radical change and limited timeframe. All this concerned with engaging and debating on the proposed educational needs by reviewing the apartheid curriculum, and thereby completing the curriculum policy guidelines for articulating the envisaged curriculum for teacher qualification. The issue of resistance to change, which was highlighted by the pro-change educationists, Chisholm (2005) and advocates of the South Africa National Qualification framework and South African Qualification Authority (Department of Basic Education, 1998), became a matter of general concern when academics voiced their concerns, namely because not all academics had the expertise in curriculum design and development. The rejection of curriculum structures designed under the auspices of the introduced policy guidelines which universities submitted to the Higher Education Qualification Council was a frustration to historically Black and disadvantaged institutions because the rejection of the curriculum meant that teaching qualifications offered did not receive accreditation. Among other challenges emanating from the transformation was the amalgamation of the previous teacher education and training colleges and technical colleges with universities, which complicated the entire atmosphere under which the change of teacher education and training was undertaken in universities. The historical background of racial, cultural, and language-divided institutions entrenched by the policies of the apartheid educational dispensation could not be ignored in this study which intended to understand the transformation of the curriculum because the curriculum design and development imply philosophical, psychological, sociological, and historical foundations. The diverse and contesting opinions and beliefs about the philosophical and psychological principles underpinning the curriculum are likely to be thrashed out quickly and easily. The work undertaken by this study identified universities that were amalgamated and the so-called traditional universities to explore the incorporation of policy proposals in the developed curriculum documents for Minimum Requirements for Teacher Education Qualifications (MRTEQ).

\section{Background}

The Minister of National Education, Kadar Asmal, emphasized the importance of outcomes-based education and competence-based assessment in teacher education and training. The new paradigm was to replace what the minister referred to as the old grammar school approach, which in his view, was simply 
not appropriate for the demands of the $21^{\text {st }}$ century. The minister condemned the grammar school approach for emphasizing the form rather than knowledge, skills, values, and attitudes (Department of Education, 2002:1-2). As a result, the Department of Higher Education and the South African Qualification Authority gazetted competence and an outcomes-based approach to assessment in the Higher Education Qualification Framework, which regulated the transformation of traditional content-driven assessment to competency focused assessment. However, research has revealed in previous findings that the transformed curriculum for teacher education has failed to produce quality and competent teachers in twenty years, particularly in Sciences and Mathematics education.

The findings highlighted in the works of Booi and Khuzwayo (2018) revealed that even though the Higher Education Qualification Council (HEQC) accredited a Bachelor of Education qualification based on the curriculum structures, there were however challenges and difficulties encountered by teacher educators to reach consensus on selected content and approaches to teaching and learning. The aspects such as the sequencing of content knowledge, selection of content, and agreeing on the pedagogy to integrate knowledge for Life Science teachers were contested, and subsequently, the whole process was manipulated by those in authority to ensure that the status was maintained.

The findings highlighted in Booi (2019), as well as the recommendations in Murdoch and Grobbelaar (2004) and Beets (2009), raised questions about the incorporation of applied competences, integration, and quality assurance assessment in the revised Life Science curriculum. The problem statement from which the questions were derived incorporated the applied competencies in teaching, learning, and assessment in the revised Life Science course guide for teacher education and training. Beets (2009) pointed out that the Department of Higher Education and Training considered competence-driven assessment to address the inadequacies in the evidence of proficiency of knowledge, skills, and abilities that attribute a teaching qualification to a particular level of competency. The Department of Higher Education and Training (2019), in the same rhetoric of under-performance of teachers, contended that the type of teachers that were produced during the apartheid era's education dispensation and by the Norms and Standards curriculum were equipped with technical skills, hence they were unable to integrate theoretical knowledge and practical knowledge. The shift in the focus in teaching, learning, and assessment in the Minimum Requirement for Teacher Qualification introduced the integration of knowledge in terms of epistemologies, theoretical and philosophical, in the field of science, and integration of learning, with an emphasis on theoretical knowledge and practical knowledge, situational and work-related knowledge. According to Beets (2009), formative and summative assessment catalyzes both teaching and learning guides and supports the processes aimed at attaining the applied competence.

This work considered the issue of curriculum development to run in parallel with the planning of assessment. The problem statement in this work was the evidence of the acknowledgment or heed given by the curriculum developers to 
incorporate the SAQA assessment guidelines for higher education and training in the course guide for Natural Sciences.

\section{Literature Review}

This section discusses the conceptual understanding of competences and assessment in the context of curriculum change in teacher education and training. The ideas, opinions, and interpretations of the concepts of competence and integrated assessment in Killen (2015), the Department of Higher Education and Training (2019), the South African Qualification Authority (2001, 2019); Gravett and Geyser (2004); Biggs (2016) informed the operational meaning of quality assurance and competences as conceptualized in this paper. Killen (2015) argued that the concept of 'competence' in the South African educational context is conceptualized in terms of the integrated performance of abilities, skills, and knowledge demonstrated in learning. The Department of Higher Education and Training (2019) and the South African Qualification Authority (2001, 2019) further describe ' assessment of applied competences' as specified evidence of the level of proficiency. According to the Minimum Requirement of Teacher Qualification, the assessment of integrated teaching and learning in teacher education should focus on the demonstrable performance of foundational, practical, and reflexive competences. The three competences target different but coherent understanding of academic and professional skills and abilities, the foundational competence is about the performance or demonstration of knowledge and thinking that underpin educational practice, while the practical competence, which is the ability to apply theoretical skills and abilities, in an authentic context such as; decisions and actions to implement knowledge. The reflexive competence is evident when students integrate or give accounts for actions considered to implement theoretical knowledge in the foreseen and unforeseen conditions in authentic contexts or situations. The detailed descriptions and the emphasis on the competences and integrated assessment in the Department of Higher Education's Minimum Requirement for Teacher Qualification policy guidelines, and assessment regulations and guidelines, are interpreted in this work to imply that the selected instructions for teaching and learning and assessment are aligned with the three competences. Besides, the choices of techniques for gathering evidence of students' performance are relevant to the exit level outcomes and attributes of a competent teacher as proposed in the policy documents of the Department of Higher Education and South African Qualification Authority.

According to Gammie and Joyce (2009); Lassnigg (2018); Whalley (2004), an assessment plan is an integral part of selecting, sequencing, and organization of the instructions or curriculum. In the same vein, Biggs (2016); Burner (2018) spoke about the assessment plan as the alignment of outcomes and criteria, assessment tasks, and assessment techniques. The ideas and opinions of Biggs on assessment inform his work in terms of the fundamental issues that developers of the curriculum for teacher educators should have considered in the assessment plan for the course guide.

The assessment guidelines and regulations of the South African Qualification Authority (2019) also provided descriptions of the competences and exit levels 
that were to be considered in the assessment plans. For example, the foundational competences, practical competences, and reflexive competences are referred to as applied competences in teacher education and training. An assessment of foundational competence focuses on the evidence of academic and professional abilities and skills performed by students in the following components: specialized knowledge of the subject, which entails the in-depth understanding of the philosophical foundations or epistemological theories involved in the knowledge production in the field and other related areas. The criterion for assessing foundational competence has to be articulated on the premise that the envisaged competent teachers, in terms of SAQA, should be researchers and lifelong learners, interpreters of curriculum documents, designers of learning material, and mediators of learning. Assessment should also prove that students in the teaching profession demonstrate competent communication skills, interpret statistical knowledge, read academic and professional texts. In addition, qualified, experienced teachers should demonstrate understanding of integrating philosophical and theoretical knowledge in their own studies, selected from a wider field of expertise that frames the content of teaching and learning in the subject area, illustrating a sound understanding of pedagogical strategies for effective learning (South African Qualification Authority, 2019; Department of Higher Education and Training, 2015, 2019).

SAQA $(2001,2019)$ and the DHET (2019) vividly stated that the fundamental principles that should underpin planning and the process of competence-based assessment to be integrated assessment and continuous assessment. Integrated assessment implies clustering learning outcomes and assessment criteria into assessment tasks (SAQA, 2019). Assessment should be focused on candidates' ability to comprehend and master the theoretical or factual content knowledge, apply their theoretical knowledge to solve work-related problems and give an account of the efficacy of strategies and methods in educational practice (Barnett, 2018). Assessors should use a range of techniques that will allow candidates to demonstrate the applied competence without being required to teach in authentic contexts. Strategies and procedures for competence assessment should align with the purpose and exit level outcomes of the qualification (Department of Higher Education and Training, 2015). Proponents of competence-based assessment also commend the utilization of various options, such as case studies, problem-solving tasks, a portfolio of learning, material, and projects, instead of written assignments, tests, and examinations (Van der Vleuten, Sluijsmans \& Brinke, 2017; Gessler \& Peters, 2020; Boyer \& Bucklew, 2019; Black \& McCormick, 2010). The moderation process of competence assessment tools entails reporting on results and achievements in students' performance. In this context, moderation involves internal and more external moderators focusing on; the standard of achievement of competence, the validity and reliability of the assessment strategies, and design and criteria concerning the purpose and exit level outcomes of the qualification (Liviu, 2020; Engleberg et al., 2017). Moderators of competence assessment could be from higher education institutions that are deemed qualified as moderator assessors, services tutors, and outside assessment agencies (Ramesh, Raju, Reddy, Krishnan, Biswas \& Umamaheshwari, 2019). According to Navio et al. (2019); 
Cebrián et al. (2020); Mulder (2019); Lassnigg (2018); Crisp (2012) competencebased teaching, learning, and assessment allow not only the clustering of abilities, skills, and attitudes but also the motivation that is developed gradually throughout the education and training process.

\section{Methodology and Data Collection}

The primary source of data in this study was the course guides obtained from the higher education institution accredited by the HEQC from 2015 to 2017. The assessment plans are conceptualized in this work as guidelines for gathering evidence of proficiency in the performance of competences (foundation, practical and reflexive) by students, which are fundamental aspects of curriculum design and development. The Minimum Requirement for Teacher Qualification (2015, 2019) and the Norm and Standards (1998) assert that learning outcomes, credits, and exit level outcomes must adhere to the South African Qualification Authority's Higher Education Qualification framework levels. This adherence implies the alignment of articulated learning outcomes and assessment criteria in the course with the number of credits, exit level, and the three competences. According to SAQA guidelines, qualification exit level outcomes should be an overall judgment or summative assessment to profile the student's achievements according to the qualification attributes. These outcomes enshrine the seven roles and competences stipulated in the Department of Higher Education Training (2019), which are: interpreter and designer of learning programs and material, assessor, leader, administrator and manager, community, citizenship, and pastoral role, learning mediator, scholar, researcher, and lifelong learner and learning area/subject/discipline and phase specialist.

\section{Data Analysis}

The findings presented in this work resulted from the data analyzed qualitatively from documents voluntarily supplied by Life Science teacher educators in the Science Education Departments of six faculties of education in South Africa. Six course guides were used to gather information concerning the assessments of the competences and exit level outcomes, tools, and alignment of these aspects in the course guides. The Biggs Critical Alignment theory was used to analyze data. The Critical Alignment theory is implicated in the South African Qualification Authority policies on quality assurance assessment. According to Biggs (2016), outcomes-based assessment of applied competences should align with the course learning outcomes and criteria, tasks, and assessment tools, and these are to be reflected in the course guides. Gravett and Geyser (2004) and Killen (2015) refer to course guide learning outcomes as the statement defining the expected knowledge, abilities, and skills to be demonstrated by students by the end of the module or course.

In contrast, criteria indicate the performance that will be the evidence of the competence displayed by students. Finally, the tools or techniques refer to the instruments and strategies utilized to gather valid and reliable evidence of the performance of abilities, skills, and knowledge.

The process of data analysis started by identifying categories of data before classifying the items specified. The types were learning outcomes, assessment 
criteria, assessment tools and techniques. Then, results were tabulated under three categories.

Table 1: Data showing the assessment planning from the course guide coded as learning outcomes and assessment criteria.

\begin{tabular}{|c|c|}
\hline $\begin{array}{l}\text { Learning Outcome/Year Level 4/NQF Level } 7 \\
\text { Development of scientific knowledge and } \\
\text { understanding in general in the South } \\
\text { African context. } \\
\text { Development of science process skills. } \\
\text { Critical engagement with and reflections on } \\
\text { Life Sciences as a subject of historical, } \\
\text { political, economic, and sociological } \\
\text { perspectives to review current practices in } \\
\text { LS education in a more socially responsible, } \\
\text { responsive, and humanizing manner. } \\
\text { Describe and explain the nature of science } \\
\text { and critical characteristics of Indigenous } \\
\text { Knowledge (IK) } \\
\text { Discuss and reflect on the nature of Life } \\
\text { Science and its importance as a school } \\
\text { subject. } \\
\text { Describe and explain the scientific methods } \\
\text { and limitations. } \\
\text { Identify opportunities and strategies for the } \\
\text { effective integration of IK into LS lessons. } \\
\text { Critically comment on the C2005 and NCS } \\
\text { for LS. } \\
\text { Develop an in-depth understanding of } \\
\text { selected themes/topics of CAPS Grade 10- } \\
12 \text { Life Sciences content. } \\
\text { In-depth understanding of LS content and } \\
\text { knowledge in both pedagogy and } \\
\text { pedagogical content knowledge of the } \\
\text { subject. }\end{array}$ & $\begin{array}{l}\text { Assessment Criteria } \\
\text { - } \quad \text { Activities } \\
\text { - } \begin{array}{l}\text { Projects/assignments/Tests: } \\
\text { Unit and Activities }\end{array} \\
\text { - Ability to critically engage with } \\
\text { and reflect on Life Sciences as a } \\
\text { subject of historical, political, } \\
\text { economic, and sociological } \\
\text { perspectives to review current } \\
\text { practices in LS education in a } \\
\text { more socially responsible, } \\
\text { responsive, and humanizing } \\
\text { manner. } \\
\text { - No assessment criteria } \\
\text { - No assessment criteria } \\
\text { - No assessment criteria }\end{array}$ \\
\hline
\end{tabular}

Table2: Data showing the alignment of learning outcomes, criteria, tools, and techniques.

\begin{tabular}{|l|ll|}
\hline $\begin{array}{l}\text { Formative assessment and learning } \\
\text { will be assessed continuously, both } \\
\text { informally and formally. }\end{array}$ & $\begin{array}{l}\text { Assessment activities: observations, } \\
\text { oral questions, class activities, } \\
\text { assignments, tests, and final } \\
\text { examination }\end{array}$ \\
& $\begin{array}{l}\text { Activities } \\
\text { Projects/ assignments/ tests }\end{array}$ \\
\hline$\circ$ Summative Assessment & $\circ$ Tests, examinations \\
& \\
\hline
\end{tabular}


Table 3: Weighting of assessment in terms of continuous and summative evaluation.

\begin{tabular}{|c|c|c|c|}
\hline Term 1 & Term 2 & Term 3 & Term 4 \\
\hline Test $75 \%$ & Test $75 \%$ & Test $75 \%$ & Test 75\% \\
\hline March & June & September & November \\
\hline Cass 25\% & Cass $25 \%$ & Cass 25\% & Cass 25\% \\
\hline
\end{tabular}

\section{Findings}

The data presented in Tables 1, 2 and 3 reflect the items considered essential for inclusion into the assessment of Life Science course guides for teacher education, which are:

\section{Issue1: Selection of learning outcomes and assessment criteria}

According to the South African Qualification Authority, course exit outcomes are broad statements that describe the competencies to be accomplished by students by the end of the course. Data in Table 1 provides the evidence of learning outcomes, which point to the abilities and skills to be demonstrated by students, for example, 'describe and explain the nature of science and key characteristics of indigenous knowledge,' 'describe and explain the scientific methods and limitations,' and 'identify opportunities and strategies for the effective integration of indigenous knowledge into LS lessons. However, the omission of the statement describing proficiency levels in the course guides was in contrast with the Minimum Requirement for Teacher Qualification. According to the South African Qualification Authority's Higher Education Qualification Framework (2019) and Biggs (2016) learning outcomes should focus on three applied competences, namely: fundamental competences, practical competences, and reflexive competences. The learning outcomes on the course guides for Life Sciences analyzed for this work did not reflect the link between the learning outcomes and the three competences stated in the South African Qualification Authority guidelines. In addition, the data presented in Table 1 shows that the assessment criteria for other learning outcomes were missing.

\section{Issue2: Alignment of learning outcomes, assessment criteria, assessment tasks and assessment techniques and tools.}

The data in Table 2 reflect the information provided in the course guide on how the assessment of the instructions selected in the Life Sciences course was organized and planned. The data shows that learning outcomes and assessment criteria were presented as separate and unrelated items. Similarly, assessment activities and techniques or instruments did not reflect any link. According to Biggs Constructive Alignment theory, for the practical assessment of competences and criteria in the outcomes-based assessment, the learning outcomes, assessment criteria, the assessment tasks and the instruments and techniques should be aligned. The alignment of these items in an assessment focuses on the applied competences being assessed and the evidence of the level 
of proficiency demonstrated by the student in performing knowledge, skills and abilities targeted as competences. According to Martinez and Hurtado (2018), techniques in the assessment such as group assessment, individual assessment or self-assessment, and peer assessment are crucial in the assessment of competences, and assessment tasks designed for these assessment techniques should be linked to competences and tools to gather authentic, reliable, and valid evidence of the performance of the proficiency standards or level of knowledge, skills, and abilities.

\section{Issue3: Weighting of summative and continuous assessment}

Data presented in Table 3 reflects the distribution of the weightings that portray the reliance on tests for gathering evidence about students' performance at the end of each of the four terms. The allocation of 75 percent weighting to summative assessment and twenty-five percent to continuous assessment proves that Life Sciences teacher educators did not consider aligning teaching, learning, and assessment to applied competences. According to Barnett (2018) and Killen (2015), the South African Qualification Authority (SAQA) (2019) assessment should be an integral part of teaching and learning, and that the focus should be on the three applied competences in higher education: foundational, practical, and reflexive. Similarly, Cebrián et al. (2020), and Beets (2009) proposed the application of a portfolio to gather evidence of competent performance, to provide students the opportunities to demonstrate competency of mastery of content knowledge, the ability to apply their conceptual understanding in various contexts of teaching and learning in the workplace, and to reflect on their professional practice to implement curriculum changes in work-related contexts (Barnett, 2018; South African Qualification Authority, 2019). Beets (2009) argued that formative assessment catalyzes the process of teaching, learning and assessment; therefore, the uncertainties concerning alignment of learning outcomes and assessment criteria hinder the role of the formative assessment to provide students with the constructive feedback that is necessary for development and improvement in their teaching and learning. Barnett (2018) is clear about the benefits of formative assessment in providing students with the opportunity to learn from their mistakes and to put in additional effort to improve those mistakes. In the same view, Cebrián et al. (2020) argued that the demonstration of proficiency in competences is a process, not an event.

Issue 4:The mixture of content-based and outcomes-based principles in the planning of teaching, learning and assessment.

Data in Tables 1 and 2 highlighted the omission of terminology such as foundational, practical, and reflexive competences in the Life Science course guide. According to the Department of Higher Education and Training (2019); SAQA (2019), the minimum requirement for a teacher qualification should integrate outcomes-based and competence-based assessment when gathering evidence about foundational, practical, and reflexive performance competences in teacher education and training. Data in Table 1 highlights uncertainty in the statements describing the learning outcomes and assessment criteria. According to Killen (2015), the South African Qualification Authority's (2019) learning 
outcomes in teacher training should describe the expected competences to be developed in each unit of the course, and attached to the learning outcomes should be the criteria that indicate the expected performance which determines the accomplishment of the proficiency levels. The figures showing the weightings allocated to formative and summative assessment and the assessment techniques presented in Table 2 were not aligned to any of the competences stated in the curriculum policy for teacher education and training in DHET (2019). Data in Table 1 and Table 2 reveal the bias of the developers to content-based assessment in the designs of assessment activities, the omission of the applied competences, and the inadequate description of learning outcomes and assessment criteria which are evidence of the compromise of competencebased assessment.

The learning outcomes and assessment criteria were haphazardly articulated without careful consideration being given to an adequate alignment with the relevant applied competences; foundational, practical, and reflexive competences. The repeat of the statement, for example, "in-depth understanding of NS content and knowledge in both pedagogy and pedagogical content knowledge of the subject," as both a learning outcome and an assessment criterion is evidence of the uncertainty that is reflected in the revised Natural Sciences study guides as highlighted in Table 1 . The same statement in Table 1 fell under the views categorized as assessment criteria for example: "An ability to critically engage with and reflect on Natural Science as a subject of historical, political, economic, and sociological perspectives to review current practices in NS education in a more socially responsible, responsive and humanizing manner."

\section{Discussion and Interpretation of Findings}

The interpretation of the findings in this section reflects the ideas and opinions discussed under the literature review and those of Biggs' Constructive Alignment theory. The findings based on the data in Table 1 regarding the learning outcomes and assessment criteria highlight an inadequate conceptualization of terminologies defined in the South African Qualification Authority's guidelines on assessment in higher education and training. According to the proponents of competence-based assessment in professional education and training, learning outcomes should be a broad statement describing intellectual and practical abilities attached to the knowledge and skills which the course will have equipped students with by the end of the units or themes (Betts et al., 2019). The unclear descriptions of learning outcomes in terms of competences revealed by the data in Table 1 and 2, which is interpreted in this work to be a threat in the transformation of teaching, learning and assessment of pre-service Natural Sciences teachers. Barnett (2018) argued that competence-based teacher education and training emphasizes the integration of teaching, learning and assessment, and this integration ensures the implementation of continuous assessment. Continuous assessment entails applying different techniques to assist students in developing proficiency in mastering various abilities or competences articulated in the assessment criteria. In the context of continuous assessment, formative assessment aims to enrich and enhance the acquisition of skills and knowledge by examining learning, 
while summative assessment focuses on gathering evidence upon which a judgment can be made about learning progression. The weightings allocated for formative and summative assessments are viewed in this research as evidence of adherence to the Life Sciences course guides to the traditional summative assessment. According to Gulikers et al. (2018), a process of curriculum change introduces practitioners to new approaches, theories, and practices which at times require a total shift from traditional techniques; therefore, some misconceptions of new terminologies are inevitable during the process of curriculum change, most notably at the level of adaptation.

\section{Conclusion}

The study's findings highlight the issues of uncertainty in the articulation of the course's learning outcomes, assessment criteria and the planning of continuous assessment. The conclusions of this study confirm matters that had already been pointed out by previous researchers, Barnett (2018); Carl (2010); Beets 2009; Betts et al. (2019), namely adherence to the traditional practices, resistance to change, the incapacity of adequate support and supervision. The study also concluded that competences and criterion-referenced principles are not considered part of transforming teaching, learning, and assessing Life Sciences teachers' curriculum knowledge and qualifications. The proponents of quality assurance of assessment recommend that competence in the outcomes-based assessment requires an alternative approach to the moderation of assessment techniques and instruments for gathering evidence on their performance (Murdoch and Grobbelaar, 2004; Bergsmann et al., 2018). Further, the researchers recommend a shift from the practices of internal and external moderation practices that focus on the examination system in higher education to ascertain whether the questions contained in the summative assessment tools adhere to the Blooms Taxonomy and the principles of fairness, and consistency and that the postassessment moderation aims to verify that the marking of answer sheets is fair and consistent. The argument pursued in this paper entrenches the opinions and views of van Rensburg (2015)by adding that the demonstration of competences is not a single event; instead, it is a process. Moderation should therefore ensure the quality of the instruction, pedagogical approaches, learning outcomes, and the assessment tools or techniques in terms of validity and reliability to provide the evidence of the proficient performance of competences stated in the learning outcomes criteria. According to Murdoch and Grobbelaar (2004) the role of the moderator is broadened to include overseeing and verifying the teaching, learning and assessment. Hence approach implies that the moderator and the examiner should discuss the course guide and the assessment developed by the instructors and the examiners. Therefore, the report or the moderator's feedback should encompass comments and reflections on the curriculum, exit level outcomes, and achievement of the outcomes and competencies targeted in the criteria. Comments should reflect on the quality and relevance of the form content and methods and the number of assessment opportunities required, and general comments could be another way of evaluating the course (South African Qualification Authority, 2011; 2019). The non-alignment of learning outcomes, assessment criteria, assessment techniques, and assessment instruments in the Life Sciences course contrasts with Biggs' Constructive Alignment theory, which 
promotes integrating teaching, learning, and assessing competences in higher education and training.

This study concludes that the implications of uncertainties concerning the assessment of applied competences are firstly inadequately evidenced to prove the proficiency of Life Sciences teachers' performance of foundational, practical, and reflexive competences required in teaching, learning and assessment in Life Sciences classrooms. Secondly, the perpetuation of content-driven assessment focuses on scores obtained from tests as a norm to determine proficiency, with data showing the allocation of higher percentage weightings to tests in Table 2 confirming the emphasis on summative assessment techniques in the Natural Science course guides. Thirdly, this work concludes that the Natural Sciences teachers being prepared based on the course guides analyzed in this study are likely to experience difficulties implementing principles underpinning the Life Sciences curriculum innovations in the classroom. Similarly, the omission of learning outcomes and assessment criteria for practical competence in the Life Sciences course guide is interpreted as a contrast to the South African Qualification Authority (2011) assessment policy. Since this policy emphasizes the assessment of professional practice in an authentic workplace and the application of teaching and learning strategies, therefore the disregard of practical and reflexive competences in the course guides means that supervision, mentoring and support which students require to accomplish performance of a higher level of competency in professional practice is compromised. In the same vein, MRTEQ (2019) stipulates that the assessment of practical competence and reflexive competence must focus on students' ability to reflect on their own practices and lifelong learning in the workplace, and these were found to be compromised in the education and training of Life Sciences teachers. The findings also extend the concerns expressed by the Minister of Education, Asmal, regarding the grammar school trend of thought, which traditionally influenced teaching, learning, and assessment in the teacher education and training curriculum and the school curriculum.

Fourthly, evidence exists to prove that Life Sciences teachers have met the requirements and the attributes of the academic and professional teacher outlined in the minimum standards for teacher qualification policy in South Africa, and finally, the lack of adequate integration of applied competences to the teaching, learning and assessment of future Life Sciences teachers.

This work has identified the contradiction in the accreditation of the curriculum, whereby the Council of Higher Education's committee accredited the curricular despite the discrepancies identified by this study. Barnett (2018) and Murdoch and Grobbelaar (2004) recommend SAQA assessment policies for quality assurance assessment to monitor the focus of assessment practices in teacher education and training on the performance of the applied competences that are identified to be the attributes of competent and qualified teachers. Transformation of teacher education and training, in Minister of Education Asmal's view, entails integrating teaching, learning and assessment, and focusing on assessing proficiency in the performance of skills, knowledge, and abilities. However, the findings of this study point out that applied competences 
are not used to frame assessment procedures and processes, as highlighted in Table 1.

\section{Recommendations}

The findings of this study revealed the contrast in the outline of assessment activities, tools, and approaches to assessment. While the proposed assessment guidelines in MRTEQ (2019) and SAQA (2011) indicate a shift from contentbased to competence-based, the course guides highlighted the adherence to the traditional approach, which focuses on content-driven and norm-referenced assessment. The alignment of assessment tasks and tools to assessment criteria of learning outcomes, which is emphasized in the SAQA assessment guidelines, was disregarded in the Life Sciences course guides. The contradictions between the proposed national curriculum change and the institution's course guides highlighted in the findings indicate a need to review course guides. The opinions and views in the works of the advocates of competence-based assessment in higher education and training, Barnett (2018) and Wesselink et al. (2017) pointed out that assessment of competences is not an event but a process. The assessment of competences as a process is conceptualized in this paper to propose the upward development and professional growth that is monitored through continuous assessment, starting with the gathering of evidence of the proficient performance of competences from a basic level of complexity, then a higher level of complexity to the highest level. The formative assessment is a perceived procedure for supporting and monitoring development in the learning and teaching of knowledge, which focuses on the mastery of levels of complexity. The vertical articulation of learning outcomes and assessment criteria should be explicit in the course guide and reflect the three applied competences. It is recommended that future research could extend these findings by evaluating curriculum course guides in other fields. The study's findings for this work can be used as a springboard for further analysis of course guides and for further inquiry into the transformation of assessment in teacher education.

The figure presented below manifests the conceptual image of the vertical articulation of assessment criteria from fundamental to complex competences which should be reflected in the planning of the units. 


\section{basic level of complexity}

Figure 1 presents the conceptual route for the vertical articulation of learning outcomes, the three applied competences, and the assessment criteria.

The diagram could guide teacher educators and researchers to explore ways and means of designing tasks to assess the three applied competences and integrate teaching, learning, and assessment in the Life Sciences course guides. Previous research has highlighted that previous curricula for teacher education have produced teachers who have failed to adjust to the curriculum changes due to their incapacity and incompetence to demonstrate skills and ability required to manipulate the contexts in the school environment (Department of Higher Education, 2019). This study recommends applying competencies in the teaching, learning and assessment phase and the moderation of course guides to address gaps and omissions revealed in the analysis of data. Research in teacher education and training can pursue studies related to the practice of assessment in the context of quality assurance to meet the criteria - referenced by the performance of the applied competences in teacher education and training.

\section{Limitations}

The findings of this study intended to discover items, ideas and principles that inform the conceptualizing and planning of the assessment of competences in the Life Sciences course guides. However, the findings presented in this paper are subject to some limitations because the current research is qualitative in nature along with other parameters: document analysis, size of the sample and sampling strategies. In addition, it did not call for Life Sciences teacher educators' interviews, students' perspectives, and observations. 


\section{References}

Barnett, R. E. (2018). Assessment in higher education: An impossible mission? In D. Boud \& N. Falchikov (Eds.), Rethinking assessment in higher education learning for the long term 39-50. London: Routledge Falmer. https://doi.org/10.4324/978020396430910

Beets, P. (2009). Towards integrated assessment in South African higher education. InE. Blitzer (Ed.), Higher education in South Africa: A scholarly look behind the scenes (Chapter 9, 183-202. Stellenbosch: Sun Media. https://doi.org/10.18820/978192033183/09

Bergsmann, E., Klug, J. Burger, C. Först, N.,\& Spiel, C. (2018). The Competence Screening Questionnaire for Higher Education: Adaptable to the needs of a study programme. Assessment and Evaluation in Higher Education, 43(4), 537554.https://doi.org/10.1080/02602938.2017.1378617

Betts, L. R., Huntington, B., Lao L., Dillon, G. V., \&Baayard, P. (2019). Developing a competency-based education and training program for university tutors. The Journal of Competency-based Education, 4(4),1-6. https://doi.org/10.1002/cbe2.1200

Biggs, J., \& Tang, C. (2020) Constructive Alignment: An Outcomes-Based Approach to Teaching Anatomy. In L.K Chan \& W. Pawlina (Eds.) Teaching Anatomy. Springer, Cham. https://doi.org/10.1007/978-3-030-43283-6_3

Biggs, J. (2016) Teaching for quality learning at university. Buckingham, England. Open University Press.

Black, P., \& McCormick, R. (2010). Reflections and new directions. Assessment and Evaluation in Higher Education, 35(5), 493499.https://doi.org/10.1080/02602938.2010.493696

Booi, K., \& Kuzwayo, M.E (2019). Difficulties in developing a curriculum for pre-service Science Teachers South African Journal of Education, 39(3), 1-13. https://doi.org/ $10.15700 /$ saje. v39n3a1517

Boyer, N., \& Bucklew, K. (2019). Competency-based education and higher education enterprise system. The Journal of Competency-Based Education, 4(1), 1-20. https://doi.org/10.1002/cbe2.1180

Burner, T. (2018). Why is Educational Change so Difficult and How Can we Make it more Effective, Research and Change, 1(1), 122-134. https://doi.org/10.23865/fof.v1.1081

Cebrián, G., Junyent, M., \&Mulà, I. (2020). Competencies in education for sustainable development: Emerging teaching and research developments. Sustainability, 12(2), 579. http:// doi.org/10.3390/su12020597

Crisp, G. (2012). Integrative assessment: Reframing assessment practice for current and future learning. Assessment and Evaluation in Higher Education, (37) 33-44. https:// doi.org/10.1080/02602938.2010.494234

Chisholm, L. (2005). The politics of curriculum review and revision in South Africa in regional context, Compare: A Journal of Comparative and International Education, 35 (1), 79-100. https://doi.org/10.1080/03057920500033563

Christie, P. (2006). Changing regimes: Governmentality and education policy in the post -apartheid South Africa. International Journal of Educational Development, 26 (4) 373-381.https:// doi.org/10. 1016/j.ijedudev.2005.09.006

Department of Higher Education and Training (DHET). (2019). Minimum requirements for teacher qualification. Pretoria: Government Printers.

Engleberg, I. N., Ward, S. M., Disbrow, L. M., Katt, J. A., Myers, S. A., \& O'Keefe, P. (2017). The development of a set of core communication competencies for 
introductory communication courses. Communication Education, 66(1), 1-18. https:// doi.org/10.1080/03634523.2016.1159316

Gammie, E., \& Joyce, Y. (2009). Competence-based Approaches to the Assessment of Professional Accountancy Training Work Experience Requirements: The ICAS Experience. Accounting Education, 18 (5) 443-466.

https://doi.org/10.1080/09639280902719465

Gessler, M., \&Peters, S. (2020). Competency-based education and training in Namibia: Educational transfer as an imitation. In M. Pilz and J. Li (Eds.), Comparative Vocational Education Research 113-130. Wiesbaden: Springer. https://doi.org/10.1007/978-3-658-29924-8_7

Gulikers, J. T. M., Runhaar, P., \&Mulder, M. (2018). An assessment innovation as a flywheel for changing teaching and learning. Journal of Vocational Education and Training, 70(2), 212-231.https://doi.org/10.1080/13636820.2017.1394353

Gravett, S. \& Geyser, H. (2004) Teaching and Learning in higher education. Pretoria: Van Schaik

Higgs, P, (2007). The African renaissance and the transformation of higher education curriculum in South Africa. African Education Review, 13 (1) 87101.https://doi.org/10.1080/18146627.2016.1186370

Jansen, J.D. (1998). Curriculum Reforms in South Africa: a critical analysis of OutcomesBased education. Cambridge Journal of Education, 28 (3), 321-331 https:// doi.org/10.1080/0305764980280305

Killen, R. (2015). Teaching strategies for quality teaching and learning. Cape Town: Juta Publishers.

Lassnigg, L. (2018). Competence-based education and educational effectiveness. In M. Mulder (Ed.), Competence-based vocational and professional education: Bridging the worlds of work and education 667-693. Switzerland: Springer International Publishing. https://doi.org/10.1007/978-3-319-41713-4_31

Martinez, L. V., \& Hurtado, J. T. (2018). Competency-based evaluation in higher education: Design and use of competence rubrics by university educators. International Education Studies, 11(2), 118-131. https://doi.org/10.5539/ies.v11n2p118

Navio, E. P., Dominguez, M. M., \& Zagalaz, J. C. (2019). Perception of the professional competence of last year's students of pre-primary education and primary education degrees and students of training teachers' master. Journal of New Approaches in Education Research, 18(1), 58-65. https://doi.org/10.7821/naer.2019.1.344

Sayed, Y., \& Kanjee, A. (2013). Assessment policy in post-apartheid South Africa: Challenges for improving education quality and learning. Principles, Policy and Practice, 20(4),444-469. https:// doi.org/10.1080/0969594x.2013.838541

South African Qualification Authority (SAQA). (2019). Guidelines for integrated assessment. Pretoria: Government Printers.

Van der Vleuten, C., Sluijsmans, D., \& Brinke B. D. (2017). Competence assessment as learner support in education. In M. Mulder (Ed.), Competence-based vocational and professional education 607-635. Switzerland: Springer. https://doi.org/10.1007/978-3-319-4_28

Wesselink, R., Biemans,H., Gulikers, J., \& Mulder, M. (2017). Models and principles for designing competence-based curricula, teaching, learning, and assessment. InM. Mulder (Ed.), Competence-based vocational and professional education: Bridging the worlds of work and education. 533-553. Switzerland: Springer International Publishing. https://doi.org/1007/978-3-319-417-4_25 
Whalley, B. (2014). Teaching with assessment, feedback, and feed forward: Using 'preflight' to assist student achievement. InT. Bilham (Ed.), For the love of learning 114. Palgrave: MacMillan. http://doi.org/10.1007/978-1-137-33430-5_14

\section{Appendix A}

A Schedule for document analysis

\begin{tabular}{|c|c|}
\hline Course Guide & \\
\hline Aim of the Course & \\
\hline Purpose of the Course & \\
\hline $\begin{array}{l}\text { Articulated Course Learning Outcomes/ } \\
\text { Applied competences }\end{array}$ & \\
\hline Articulated Assessment Criteria & \\
\hline $\begin{array}{l}\text { Applied competence/ assessment procedure/ } \\
\text { assessment criteria/ assessment techniques }\end{array}$ & \\
\hline $\begin{array}{l}\text { Formative assessment/ tasks/techniques/ } \\
\text { applied competences/ assessment criteria }\end{array}$ & \\
\hline $\begin{array}{l}\text { Summative assessment/ tasks/ techniques/ } \\
\text { applied competences }\end{array}$ & \\
\hline Weightings & Summative \\
\hline & formative \\
\hline
\end{tabular}

